\title{
PLURALISME OIKUMENIS \\ DAN IMPLIKASI PELAYANAN PASTORAL
}

\author{
Marthen Nainupu
}

\section{ABSTRAKSI}

Hadirnya milenium ketiga dengan kecanggihan teknologinya, sudah menyatukan berbagai belahan bumi yang sebelumnya terasa sangat berjauhan, kini sudah sangat dekat bahkan telah menjadi sebuah kampung kecil. Seiring dengan hal itu telah lahir pula suatu kesadaran baru akan pluralisme, terutama pluralisme agama-agama dalam masyarakat postmodern ini dan secara lebih khusus lagi pluralisme oikumenis. Kehadiran pluralisme mendorong untuk melakukan pendekatanpendekatan baru terhadap pelayanan pastoral, tetapi sekaligus melahirkan sikap pro dan kontra di tengah masyarakat gereja. Artikel ini mencoba untuk menelusuri akar-akar pluralisme serta beberapa problem yang ditimbulkan olehnya. Fakta pluralitas di tengah kalangan masyarakat gereja menuntut suatu sikap bijak dalam merespon pluralisme oikumenis, guna membangun dan mengembangkan suatu semangat kerja sama di antara para pelayan pastoral bagi keluasan kerajaan Allah.

Kata kunci: Pluralisme, Ekskulivisme, Inklusivisme, Pluralisme oikumenis, Pelayanan pastoral yang berpusat pada Alkitab dan tradisi pelayanan pastoral.

\section{PENGANTAR}

Sadar atau tidak, saat ini kita (gereja) hidup dan berkarya di tengah semangat pemikiran pluralisme. Jika dibandingkan dengan beberapa tahun yang lalu, hampir semua pemikiran "besar" saat itu telah di kuasai oleh pemikiran tunggal dari agama, khususnya agama Kristen. Selama milenium pertama dan kedua dimana pemikiran tunggal dikuasai oleh pemikiran kristen. Sejarah telah mencatat bahwa pada masa milenium pertama maupun kedua telah terjadi suatu masa yang sadis, banyak kematian yang terjadi demi mempertahankan suatu pemikiran tunggal, yang oleh Sumartana disebut "Theological killing". Akan tetapi dengan datangnya milenium ketiga ini, semangat pemikiran pluralis, semakin bergema dimana-mana dan dapat dirasakan bahwa kebenarankebenaran tunggal dalam agama Kristen sudah mulai kehilangan kekuatan dan pengaruhnya. Semangat pluralisme ini mula-mula disadari dan digalakkan oleh para pemikir kristen sendiri seperti Hans Kung, John Hick dan Paul F. Knitter. Kini pengaruh semangat pemikiran pluralism sudah merambah ke mana-mana. 
Sebenarnya semangat pemikiran pluralisme bukanlah hal yang baru, bagi gereja atau jika kita mau melihat lebih jauh kebelakang, maka semangat pluralisme itu kita akan segera temukan juga di dalam kelahiran agama Yahudi ${ }^{2}$. Sedangkan kalau kita berbicara tentang kehadiran agama Kristen di Indoneia, memang agama kristen hadir di tengah-tengah agama lainnya. Sebab realitas Indonesia sejak awalnya memang terdiri dari kemajemukan dalam banyak hal. Hal tersebut kita semua tahu manakala para pendiri negeri kita sudah mendeklarasikan keberagaman itu, dalam suatu kalimat yang pendek: "Bhineka Tunggal Ika". Tetapi dalam perkembangan selanjutnya pemikiran tersebut mengalami berbagai kebekuan dan bahkan terkesan kecenderungan untuk melupakannya.

Bilamana kita mau menengok sedikit jauh ke belakang, kita akan segera menemukan akar-akar pemikiran pluralisme dalam tradisi pemikiran Yunani kuno. Istilah pluralitas - maupun pluralism, yang belakangan ini sangat popular, sebenarnya bukanlah suatu istilah yang baru, melainkan itu merupakan suatu istilah yang sudah usang. Hal itu kita dapat melacaknya dari para ahli pikir jaman Yunani kuno. Pada jaman pra Sokrates misalnya, gagasan pemikiran pluralisme sudah dirintis oleh Protagoras dengan slogannya yang terkenal "Manusia adalah satu-satunya ukuran bagi segala sesuatu "(Man is the measure of all things). Dari pernyataan Protagoras tersebut telah terlihat dengan jelas semangat dan benih pluralism. Tetapi kalau kita mundur sedikit ke belakang sebelum Protagoras, di sana kita menemukan Herakletus, filosof dari Efesus, ia sudah menggagas ide awal dari pemikiran pluralism. Filsafat Herakletus sering disebut dengan nama "filsafat menjadi". Artinya segala sesuatu di alam semesta ini sedang menjadi dan selalu berada di dalam perubahan, tidak ada yang tetap, semuanya mengalir. "Panta Rei Uden Menei" yang artinya bahwa segala sesuatu mengalir tidak ada yang tinggal diam". ${ }^{4}$ la mengakui bahwa realitas itu satu tetapi pada saat yang sama ia banyak dan itu bukan soal aksidental melainkan essensial.

Dalam perjalanannya, pemikiran pluralis kurang memperoleh tempat dalam kancah perdebatan filosofis. Sokrates sendiri adalah penentang utama aliran berpikir pluralis. Pemikiran pluralis semakin hilang pengaruhnya ketika dunia peradaban filsafat dikuasai oleh pemikiran filsafat dan teologi Kristen. Dalam era filsafat dan teologi Kristen, semua faham pemikiran politeisme Yunani dihapus dan diganti dengan pemikiran monoteisme Kristen. Selama masa tersebut, pemikiran pluralism boleh dikatakan hilang kekuatannya dalam berbagai diskusi filsafat.

Dalam tidur panjangnya, tiba-tiba ia dikejutkan dengan hadirnya jaman Renaisanse yang menempatkan manusia sebagai pusat pemikiran 
segala filsafat. Selama era ini pemikiran pluralis kembali bergema dan menjadi pokok diskusi para filosof, terutama para pemikir dari aliran empirisme. Pemikiran-pemikiran dengan aliran pluralism terus bergulir sejak era modern dan boleh dikatakan telah mencapai puncaknya di era postmodern ini.

Semangat postmodern dan demokratisasi telah membuka peluang yang sangat besar bagi hadirnya pluralism di tengah-tengah kehidupan umat manusia. Memang harus diakui bahwa pluralism itu merupakan bagian integral dari kehidupan umat manusia, akan tetapi pada masa sebelum era kita hari ini, gerak pluralism itu masih sangat lambat dan hanya dapat hidup dan bertahan secara local. Namun dengan datangnya era paska modern ini, maka kekuatan pluralism semakin tampil mengemuka di mana-mana. Hampir dapat dikatakan bahwa sudah tidak ada lagi batasbatas antara berbagai bagian dari kehidupan ini. Semangat pluralism telah menghapus semua pemikiran tunggal dan menggantikannya dengan pemikiran pluralism. Dalam bahasa Nietzsche, kebenaran adalah selalu bersifat perspektifal. Artinya kebenaran selalu berada dalam perspektifperspektif tertentu. Di sini terlihat dengan jelas semangat pluralism yang berujung kepada semangat relativisme, kekosongan dan kehampaan. Ekses-ekses seperti inilah yang memunculkan berbagai reaksi terhadap pemikiran-pemikiran pluralism. Kalau kita mau melacak lebih jauh lagi soal pro dan kontra tentang pluralisme, kita bisa membuat buka dengan beratusratus halaman, sebab yang mendukung maupun yang menolak sangat banyak, baik teolog, filosof, maupun awam. Pluralisme telah memecah keseragaman berpikir dalam kelompok, misalnya para teolog dari gerejagereja Timur lebih senang dengan pluralisme, sedangkan teolog dari gereja-gereja barat lebih cenderung menolak pimikiran pluralisme ${ }^{5}$. Memang memperdebatkan soal apa itu pluralisme, tidak akan pernah habis-habisnya. Melalui tulisan ini saya mencoba untuk memahami pluralisme dalam kaitannya dengan pelayanan pastoral. Dengan demikian, percakapan ini hanya akan menampilkan sekilas beberapa pemikiran pro maupun kontra. Tetapi yang lebih utama ialah bagaimana para pelayan pastoral mengembangkan suatu sikap penuh empati untuk memanfaatkan semangat pluralisme ini bagi keutuhan pelayanan.

\section{APA ITU PLURALISME}

\section{Memahami pluralisme}

Dari percakapan sebelumnya kita sudah melihat sekilas mengenai akar-akar pemikiran pluralisme dari pemikiran filsafat, tetapi apakah 
pluralisme itu? Ada baiknya, sebelum kita pahami bersama apa itu pluralisme, dijelaskan lebih dahulu istilah pluralitas dan pluralisme yang kedua istilah itu berasal dari akar kata yang sama. Kedua istilah tersebut (pluralitas dan pluralism) berasal dari akar kata yang sama yaitu kata "pluralis" dari bahasa Latin atau kata "plural" dari bahasa Inggris. Diharapkan dengan adanya distingsi antara pluralitas dan pluralisme akan terlihat semakin jelas apa itu pluralisme. Sebab sering kali kedua istilah ini dipakai secara tumpang tindih dengan pengertian dan makna yang sama saja. Di samping itu perjelasan tersebut dimaksudkan agar kita memiliki pemahaman yang sama mengenai kedua istilah tersebut dan secara khusus kata pluralisme yang saya gunakan dalam paper ini.

Pluralitas diterjemahkah dari kata "plurality" yang termaknai sebagai keberagaman, kemajemukkan, kejamakkan. Kata pluralitas itu hampir sama maknanya dengan kata "kebhinekaan". Kebhinekaan atau keberagaman seperti itu, memang adalah suatu realitas universal yang kita dapat temui di mana-mana di seluruh dunia. Di Indonesia saja, kejamakkan sebagai realitas sosial adalah merupakan suatu kenyataan, misalnya kemajemukan suku, bahasa, budaya, adat istiadat, agama. Jadi pluralitas adalah suatu deskripsi objektif atas atau terhadap realitas manusia dan alam yang terdiri dari banyak hal yang beragam. Jadi kalau dalam percakapan sehari-hari dan kita gunakan kata "pluralisme agama" ini salah kaprah. Karena yang dimaksud dengan "pluralisme agama" dalam percakapan tersebut adalah pluralitas agama yaitu bahwa memang di Indonesia terdapat lima atau enam agama. Jadi sekali lagi, istilah pluralitas lebih menunjuk kepada jumlah atau banyaknya agama, bahasa, budaya dari pada perbedaan yang satu dengan yang lainnya.

Pluralisme sering diartikan sebagai sebuah paham (isme) suatu perspektif ideologis - filosofis dalam memahami realitas. Pluralisme bukan sekedar soal kepelbagaian, bukan hanya soal jumlah, banyak atau sedikit, majemuk atau tunggal, melainkan ia merupakan suatu paham (isme.) Pluralism sebagai paham, mencoba untuk merangkul realitas pluralis dalam suatu kesetaraan. Terhadap pluralisme agama atau keselamatan yang disediakan agama, pluralisme berkeyakinan bahwa ada banyak jalan menuju ke keselamatan. Tekanannya ada pada Allah sebagai pusat, atau realitas tertinggi dan realitas tersebut dapat dipahami melalui berbagai persepsi yang berhubungan dengan kebenaran. ${ }^{7}$ Upaya-upaya semacam ini dilakukan dengan maksud untuk menghilangkan berbagai pergesekan dan perbedaan yang sering kali terjadi dan memicu berbagai konflik sosial dalam masyarakat. Oleh karena itu paham pluralism mencoba untuk mencari solusi terhadap berbagai konflik dengan meniadakan klaim-klaim kebenaran. Pluralisme memberi tekanan pada kualitas keberagaman sebagai realitas. Dengan paham pluralism, maka setiap keunikkan yang terdapat pada suatu pandangan atau agama, direlatifkan makna dan kebenarannya. Paham pluralis mencoba untuk menghapus kebenaran- 
kebenaran tunggal dan menggantikannya dengan kebenaran-kebenaran pluralis-relatif. Pemikiran semacam ini kita dapat melihatnya di dalam pandangan dari Knitter $^{8}$. Dari perspektif tersebut di atas, maka pluralisme yang dibicarakan bukan lagi penyajian suatu data deskriptif terhadap realitas, melainkan suatu sikap pandang dalam memahami dan memaknai realitas yang majemuk.

Sikap pandang terhadap realitas tersebut didorong oleh berbagai peristiwa berdarah yang terjadi belakangan ini. Dalam berbagai analisis, terutama analisis sosiolgis, ditemukan bahwa berbagai konflik sosial dan peristiwa berdarah yang terjadi di berbagai tempat telah dipicu oleh klaimklaim kebenaran ${ }^{9}$. Klaim-klaim kebenaran itu misalnya budaya, adat istiadat dan terutama klaim kebenaran agama. Lahirnya ide pluralisme didasarkan pada sebuah keinginan untuk melenyapkan klaim kebenaran yang dianggap menjadi pemicu munculnya sikap ekstrem, radikal, perang atas nama agama, konflik horisontal, serta penindasan atas nama agama. Menurut kaum pluralis, konflik dan kekerasan dengan mengatas namakan agama baru akan bisa sirna jika masing-masing agama tidak lagi menganggap agamanya yang paling benar. Maka para penganut semangat pluralism mengajukan solusi yaitu harus dihapuskannya berbagai klaim kebenaran, maka di situ akan tercipta kehidupan yang rukun dan damai.

Sebenarnya pluralisme itu sendiri masih dapat dikelompokkan ke dalam tiga kelompok. Kelompok pertama disebut pluralism tradisional. Mengenai pluralisme tradisional ini Wahono ${ }^{10}$ menyebutnya sebagai tahap Ignorant, dimana masing-masing penganut agama tahu bahwa ada agama lain di sampaing agama saya, tetapi masing-masing penganut agama berjalan sendiri-sendiri. Tidak saling mengganggu dan tidak saling mempedulikan satu sama lain. Mereka menerima saja perbedaanperbedaan tersebut sebagai sesuatu yang bersifat alamiah. Kedua ialah kelompok pluralism terbatas, dimana masing-masing penganut agama berjuang untuk menemukan kebenaran menurut agamanya sendiri yang bersifat eksklusif. Di sinilah sebenarnya awal mula klaim-klaim kebenaran muncul kepermukaan. Pluralisme ketiga ialah apa yang kita kenal dewasa ini yaitu pluralism "ekstrim" sebagai sebuah paham. Pluralisme dewasa ini sudah menjadi ciri utama dari kehidupan sosial. Sesungguhnya dunia kita dewasa ini sudah menjadi sebuah kampung kecil yang sangat heterogen di mana umat manusia hidup bersama di dalamnya. Bukan hanya hidup bersama tetapi tiap-tiap orang sudah mengalami proses emansipasi, dan sadar akan hak-haknya untuk berpendapat. Sadar akan kenyataan semacam ini, munculkan semangat pluralisme hari ini.

Skeptisisme. Sekilas, banyak orang mempunyai anggapan bahwa pluralism sama artinya dengan skeptisisme atau sebaliknya. Namun kalau kita perhatikan dengan lebih teliti, kita akan segera tahu bahwa kedua istilah tersebut tidaklah sama artinya. Skeptisisme adalah sebuah paham yang 
mengatakan bahwa manusia dengan akal budinya tidak akan pernah mencapai kebenaran sejati. Maka kebenaran satu-satunya ialah meragukan semua kebenaran ${ }^{11}$. Skeptisisme mengatakan bahwa manusia tidak mungkin mengetahui persesuaian antara pengetahuan dengan kenyataan. Budi manusia tidak dapat mengenal realitas seperti dalam dirinya sendiri. Skeptisisme semacam ini muncul dalam bentuk relativisme dan individualisme ${ }^{12}$. Bagi penganut skeptisisme mereka mengatakan bahwa segala kebenaran hanya berlaku bagi subjek tertentu dalam situasi tertentu pula. Jadi ada perbedaan yang mendasar antara pluralisme dan skeptisisme. Di dalam pluralisme kita masih bisa menemukan kebenaran, meskipun menurut paham ini, kebenaran itu terbatas, tidak lengkap. Sedangkan di dalam skeptisisme kita tidak akan pernah menemukan kebenaran, karena pencari kebenaran itu sendiri pada dasarnya adalah terbatas. Memang ada beberapa pemikir seperti Alan Race yang menggolongkan pluralisme ke dalam varian relativisme, tetapi beberapa pengamat lain lagi seperti Knitter melihat bahwa pluralisme dan relativisme sebagai dua cara pandang yang berbeda, meskipun kadang berdekatan ${ }^{13}$.

Pluralisme sebagaimana dijelaskan di atas, sebenarnya bukanlah pluralisme yang mengalir dari pemikiran filsafat, melainan lahir dari realitas sosial yang memang plural dan keadaan itu terus berkembang dengan begitu cepat di era kita ini, serta membawa beberapa dampak negatif seperti konflik-konflik sosial. Maka pluralisme ini sebenarnya merupakan suatu usaha untuk meredam berbagai konflik sosial. Pluralisme semacam ini juga merupakan kelanjutan dari sikap-sikap masyarakat agama terhadap realitas plural.

\section{Beberapa Sikap Terhadap Pluralisme}

Setelah kita melihat apa itu pluralisme, kini kita mencoba lagi untuk melihat beberapa sikap terhadap pemikiran pluralisme. Secara deskriptif dapat diklasifikasikan menjadi tiga sikap utama.

Pertama paradigma eksklusive Paradigma eksklusivisme merupakan pandangan yang dominan di sepanjang sejarah agama-agama dan tetap dianut pemeluk agama sampai saat ini. Inti pandangan eksklusivisme ialah bahwa agama yang dianut seseorang adalah satusatunya jalan yang sah, benar menuju keselamatan dan Sorga. Pandangan ini menyebar di semua agama wahyu di seantero dunia ini. Di kalangan agama kristen, Yesus dipahami dan diyakini sebagai satu-satunya jalan menuju ke keselamatan ( Yohanes 6 : 14, Kisah Para Rasul 4 : 12) Pandangan ini merupakan pandangan yang sangat klasik dan dipegang teguh oleh hampir semua orang kristen dari berbagai aliran dan denominasi.

Dalam pergaulan sehari-hari di tengah-tengah masyarakat, pandangan ini akan termanifestasi dalam beberapa sikap lagi. Sikap 
pertama dari paradigma eksklusif adalah sikap menarik diri. Dari segi sosiologis, apabila dalam suatu komunitas dimana penganut agama tertentu merasa dirinya lebih kecil dari segi jumlah dan pengaruh, maka ia akan lebih cenderung menarik diri dari realitas sosial yang majemuk dan membentuk komunitas eksklusif, tertutup dalam pergaulan. Dalam keadaan tertentu, mereka cenderung "menjauhkan diri dari pengaruh mayoritas ke daerah yang terpencil"14

Sikap kedua dari paradigma eksklusif ialah sikap menyangkal kehadiran agama lain dengan melakukan tindakan depresif. Lagi-lagi dari segi sosiologis, apabila dalam suatu wilayah tertentu dan terdapat suatu golongan agama tertentu yang merasa lebih besar dalam jumlah maupun pengaruh maka ia akan melakukan protes-protes terbuka terhadap kelompok agama lainnya yang menurut golongan tersebut agama merekalah yang benar dan agama lainnya adalah salah bahkan sesat. Kelompok mayorits menciptakan suatu mitos bahwa merekalah yang dipanggil untuk berkuasa dan menentukan jalannya masyarakat. Semua minoritas harus ditundukkan kepada keinginan mayoritas ${ }^{15}$. Oleh karena itu agama dengan penganut minoritas harus dikuasai dan ditaklukkan, baik dengan secara paksa maupun dengan cara-cara yang lebih halus.

Kedua Paradigma "Inclusive". Paradigma ini bertolak dari suatu pemikiran bahwa semua agama dengan segala ajarannya, mampu menyediakan jalan keselamatan yang dapat menyelamatkan umatnya sejauh mereka (umat) hidup dalam ketulusan hati terhadap Tuhan. Paradigma ini membedakan antara kehadiran penyelamatan dan aktivitas Allah dalam tradisi agama-agama lain. Maka di dalam perjumpaan antar umat beragama yang bebeda-beda, hampir kurang terjadi konflik sosial, karena masing-masing mengakui dan menghargai perbedaan agama.

Dalam pergaulan sehari-hari di tengah-tengah masyarakat, pandangan ini akan termanifestasi dalam beberapa sikap. Sikap pertama dari paradigma inklusif ialah sikap akomodatif. Sikap akomodatif ini lebih mementingkan keselamatan di dalam tiap-tiap agama. Oleh karena itu kebersamaan dan kerukunan menjadi pusat perhatian mereka dan tidak mempersoalkan ajaran-ajaran agama dimana terdapat perbedaanperbedaan. Agama, dengan segala ajarannya itu urusan interen agama masing-masing orang atau soal agama itu adalah urusan hati tiap orang dengan Tuhan. maka biarlah urusan masing-masing orang dengan Tuhan dan biarlah Tuhan yang tahu. Terkadang sikap ini jatuh kepada sinkritisme.

Sikap kedua dari paradiga inklusif ialah inklusif kritis. Model ini sadar akan perbedaan ajaran agama masing-masing. Oleh karena itu masingmasing umat penganut agama tertentu, berusaha untuk berpegang teguh pada ajaran agamanya. Ciri pokok dari semangat inklusif kritis ialah: Hadir di tengah masyarakat pluralis, melihat, menimbang, memutuskan dan bertindak. Pandangan inklusif kritis bisa juga disebut sebagai inklusif 
transformatif. la hadir di tengah pluralitas agama dan berjuang untuk membawa transformasi atau perubahan terhadap kehidupan sosial masyarakat. Ada semacam kesadaran bahwa sebagai sesama umat manusia, kita harus hidup dan saling menghidupkan di antara sesama umat beragama sehingga tercipta suatu masyarakat damai sejahtera. Jadi inklusif kritis mengembangkan sikap saling menghargai kepelbagaian masing-masing penganut umat beragama dengan semangat saling menghormati dan saling memberdayakan menuju masyarakat sejahtera.

Sikap menarik diri (ekslusif)?sebagaimana dijelaskan sebelumnya, adalah sikap yang tidak sesuai dengan mandat "menjadi garam dan terang" (Matius $5: 13$ - 16) di dunia. Selanjutnya sikap mengikuti arus pluralisme tanpa sikap kritis (akomodatif), juga merupakan sikap yang bertentangan dengan Roma 12 : 2. "Janganlah kamu menjadi serupa dengan dunia" (Sekuler) atau Sinkritisme.

Maka sikap inklusif kritis dengan kesadarannya untuk menjadi garam dan terang dunia dan tidak menjadi serupa dengan dunia ini, maka ia hadir, memperhatikan, memahami, menimbang, memutuskan dan bertindak adalah sikap yang tepat ${ }^{16}$. Sikap inklusif kritis dengan kehadirannya dam kemampuan memahami akan dapat mengendalikan semangat pluralisme ke suatu tatanan hidup yang lebih memuliakan Tuhan. Usaha untuk membangun sikap saling pengertian, yang dilakukan melalui dialog, sangat membutuhkan sikap kritis. Sebab semangat dialog bukan untuk menyelaraskan semua keyakinan dari tiap-tiap agama, melainkan pengakuan bahwa tiap-tiap orang beragama memiliki keyakinan yang teguh dan mutlak dan bahwa keyakinan-keyakinan ini berbeda. Dialog menurut pemikiran saya, bukan soal mencari-cari kesamaan pandangan untuk membangun saling pengertian, melainkan dalam dialog itu kita saling menyadarkan bahwa manusia itu sudah teralienasi dari Allah karena dosa. Dosa membawa kematian spiritual.

"Kematian spiritual terebut tidak lain merupakan alienasi jiwa dari Tuhan"17 Atas kesadaran tersebut, maka dialog itu sendiri hendaknya menghantar setiap orang kepada peristiwa dan Pribadi Yesus Kristus. ${ }^{18}$ Mengapa setiap orang perlu bertemu dengan peristiwa dan pribadi Yesus Kristus? Karena Injil bukan untuk sekelompok orang melainkan untuk semua umat manusia yang sudah mengalami keterasingan [alienasi] dari Tuhan.

Ketiga Pandangan Pluralisme. Pandangan ini mengatakan bahwa setiap agama mempunyai jalan keselamatannya sendiri, dan karena itulah semua klaim bahwa hanya agamanyalah adalah satu-satunya yang sah dan benar, harus ditinggalkan. Dengan kata lain pluralisme agama menghendaki agar setiap pemeluk agama dituntut bukan saja mengakui perbedaan dan hak agama lain, tetapi harus terlibat di dalam usaha 
memahami perbedaan dan persamaan guna tercapainya kerukunan dalam kebhinekaan. Bahasa populernya di tanah air kita ialah toleransi dan dialog.

Dalam pergaulan sehari-hari di tengah-tengah masyarakat, pandangan ini akan termanifestasi dalam beberapa sikap yaitu, pertama adalah sikap pluralisme eksistensial. Gerakan ini berjuang untuk menyadarkan semua umat beragama bahwa secara kodrati realitas itu plural. Artinya kita harus mengakui dan menerima bahwa realitas kosmos ini memang banyak ragamnya dan untuk itu tidak perlu dipertentangkan satu sama lainnya. Contoh dari pandangan ini ialah pelangi. Pelangi itu indah, menarik bahkan mempesona kita, karena keragaman warnanya.

Sikap kedua ialah pluralisme relativisme. Pandangan ini bergerak dari asumsi bahwa realitas mutlak itu adalah relatif. Tidak ada suatu kebenaran apapun di dalam apapun. Ini pengaruh dari filsafat Kant yang meradikalkan perbedaan antara fenomena dan noumena. Semua agama sedang dalam pencaharian akan kebenaran dan kita hanya menangkap fenomenanya saja sedangkan yang sesungguhnya tidak seorangpun yang tahu. Sikap semacam ini sangat melemahkan kebenaran yang diakui dan diyakini oleh setiap agama selama ini. Apabila kebenaran yang diyakini oleh tiap agama direlatifkan, maka kemanakah kita harus mencari dan membangun lagi kebenaran?

\section{BEBERAPA PROBLEM UMUM DARI PLURALISME}

Dari percakapan sebelumnya, sebenarnya sudah terlihat di sana-sini adanya maslaha-masalah yang ditimbulkan oleh semangat pluralisme tersebut. Atau adanya keberatan-keberatan tertentu mengenai paham pluralisme. Para penganut pluralisme berupaya untuk mendorong kekristenan bergerak keluar sehubungan dengan agama-agama lain di dunia. Akan tetapi upaya tersebut telah menjumpai perlawanan yang tidak kecil jumlahnya, sebagian berasal dari luar dan sebagian lagi berada di dalam diri kita sendiri. ${ }^{19}$ Kita tidak akan membicarakan semua masalah pluralisme di sini, tetapi saya hanya ingin melihat beberapa masalah yang secara khusus berkenaan dengan implikasi pastoral.

\section{Pluralisme sebagai problem sosiologis (keluarga)}

Jika kita ikuti alur pemikiran dari kaum pluralisme, maka pluralisme diusung sebagai solusi terhadap berbagai konflik dan kekacauan dalam masyarakat. Secara teoritis, maksud baik tersebut dapat meredam berbagai konflik sosial dalam masyarakat, namun dalam kenyataan empiris, saya justru melihat bahwa dengan hadirnya pluralisme tersebut justru menghadirkan sekaligus persoalan dalam keluarga. Yang saya maksud dengan pluralisme sebagai problem sosiologis atau keluarga ialah 
bahwa pluralisme selalu mengadung potensi konflik sosial atau kekaburan identitas. Pluralisme oikumenis yang bersifat denominasional dengan keterbukaan pikiran dan pendapat, justru menyebabkan kebingungan. Sulit bagi kita untuk melihat dan menperoleh kepastian, sebab banyak pilihan dan banyak alternatif. Sekedar contoh, mengenai liturgi ibadah, persekutuan-persekutuan dengan nyanyian-nyanyian, terlalu banyak pilihan dan kemungkinan.

Dalam konteks gereja-gereja di Indonesia, pemandangan seperti ini tidak jarang kita jumpai bahwa dalam sebuah keluarga, bahwa anggota keluarganya memiliki atau menganut sekaligus beberapa agama. Dikalangan agama Kristen sendiri, tidak jarang kita temui bahwa dalam satu keluarga anggota keluarganya menganut berbagai aliran denominasi gereja. Keberadaan mereka dalam sebuah keluarga dengan bermacammacam denominasi gereja mengandung potensi konflik dalam keluarga. Dalam keluarga dengan kepelbagaian denominasi gereja, akan melahirkan pluralisme behavioristik. Menurut para ahli sosiologi, pluralisme behavioristik merupakan inti permasalahan sosiologis. Permasalahan itu berawal dari keyakinan atau hasrat dengan nama dogma yang berbeda, aturan dan keinginan yang berbeda pula. Padahal keluarga sebagai persekutuan yang paling asli, yang membentuk seluruh keyakinan dan kewajiban moral. Pluralisme behavioristik bisa menjadi pokok permasalahan, hal tersebut bisa terjadi karena tiap-tiap aliran denominasi gereja memberi tekanan tertentu pada satu pokok ajaran atau doktrin. Dengan memberi tekanan hanya pada satu pokok ajaran, saya rasa bahwa itu adalah suatu bentuk kekaburan identitas sebagai orang kristen. Sebab orang kristen percaya bahwa Alkitab adalah firman Tuhan, tetapi mengapa hanya menekankan satu pokok saja sebagai satu-satunya doktrin? Pada umumnya masing-masing anggota keluarga mempertahankan dokrtin dari aliran atau denominasi gerejanya. Inilah yang saya sebut sebagai kekaburan identitas.

Tetapi di sisi lain mungkin mereka mengembangkan suatu sikap toleransi, saling membiarkan, masing-masing bertumbuh dengan atau menurut doktrin dari gerejanya. Bila hal ini yang dianut, maka mereka akan segera jatuh kepada kekaburan identitas yang lebih serius lagi karena akan menimbulkan kebingunan dari masyarakat sekitarnya. Dalam percakapan saya dengan beberapa keluarga yang semacam ini, biasanya mereka menyebut dirinya dengan nama keluarga "keluarga Indonesia, agama Pancasila". Dalam suasana normal, barangkali pluralisme agama atau aliran denominasi gereja dalam keluarga boleh jadi aman-aman saja. Akan tetapi manakala terjadi hal-hal yang tidak diinginkan terutama yang berkaitan dengan masalah agama atau aliran denominasi, maka di situlah akan muncul berbagai masalah. Hal-hal semacam ini bisa menyeret para anggota keluarga itu sendiri terjatuh ke dalam konflik dan pertengkaran. 
Keluarga sebagai unit paling kecil dalam masyarakat tetapi sekaligus sebagai fondasi persatuan, ternyata dengan adanya pluralisme aliran denominasi gereja sudah menjadi benih perselisihan di anatra anggota keluarga. Konsekuensi yang lebih jauh dari pluralisme aliran denominasi gereja ialah terlepasnya anggota keluarga dari ikatan akar komunitas keluarga, sebab masing-masing mengembangkan kediriannya (semangat individualisme) sendiri. Nah jika benar hal ini yang terjadi, maka menurut analisis dari Durkheim tentang masalah bunuh diri, ia menemukan bahwa salah satu sebab bunuh diri ialah karena seseorang tercabut dari ikatan akar komunitas keluarga. Bunuh diri sebagai akibat dari tercabutnya seseorang dari akar kumunitas keluarga, lebih banyak ditemukan di antara orang kristen Protestan jika dibandingkan dengan orang Katolik. Dalam analisisnya lebih jauh ia menemukan bahwa orang protestan itu lebih individual, sedangkan orang Katolik itu semangat komunalnya lebih tinggi ${ }^{20}$.

Jadi bagi seseorang dengan semangat individual, ternyata tidak kuat menghadapi tantangan, karena ia tidak memiliki dukungan sosial, manakala ia berada dalam berbagai persoalan hidup. Selanjutnya masyarakat (keluarga) seperti yang disebutkan Durkheim ialah masyarakat "Sui Generis" yang memiliki solidaritas yang didasarkan pada prinsipprinsip moral ${ }^{21}$. Keluarga sebagai unit persekutuan yang paling asli hendaknya terus mengembangkan kesadaran kolektif sebagai suatu kesatuan komunitas keluarga. Hal tersebut dapat terwujud manakala anggota keluarga secara bersama-sama memiliki satu kepastian panduan.

\section{Pluralisme Sebagai Problem Psikologis}

Dalam sebuah keluarga perlu ada sistim tata nilai yang harus dianut bersama. Pada umumnya sistim tata nilai dalam keluarga-keluarga kristen di Indonesia adalah sistim tata nilai dari orang tua, khususnya bagi anakanak yang masih dibawah asuhan mereka. Sistim tata nilai itu bisa berupa nilai-nilai agama, budaya ataupun tradisi-tradisi lainnya yang dianut oleh orang tua selama itu. Sistim tata nilai tersebut sebagai batasan dan bila mana batasan-batasan itu dilanggar maka di situ akan menimbulkan berbagai kesulitan dalam keluarga. Sistim tata nilai tersebut perlu diinternalisasikan ke dalam anggota keluarga sedini mungkin, sehingga anggota keluarga mempunyai batasan yang jelas. Apabila anggota keluarga yang kehidupan dunia moralnya terbentuk dengan baik, ia akan membangun kesadaran kebersamaan secara lebih baik, sedangkan anggota keluarga yang orientasi hidupnya di dorong oleh hawa nafsu, maka orang tersebut akan lebih cenderung untuk mengabaikan nilai-nilai moral.

Apabila tidak ada batasan-batasan yang jelas dalam keluarga, maka disitu pula akan menimbulkan banyak kesulitan. Batasan dalam keluarga diperlukan untuk mengatur berfungsinya keluarga secara utuh. Oleh karena itu baik indivudi maupun seluruh anggota keluarga, mereka dibatasi oleh batasan-batasan hubungan antar pribadi. Batasan-batasan ini berfungsi untuk menjaga otonomi keluarga. 
Apabila dalam sebuah keluarga dengan semangat pluralisme aliran denominasi gereja dan tentu dengan sendirinya sudah berlaku nilai-nilai pluralis, maka hal tersebut akan segera menimbulkan kebingungan di antara anggota keluarga. Keluarga akan terpecah-pecah oleh pandangan yang saling berbeda dan bahkan saling bertentangan, terutama mengenai hal-hal yang berkenaan dengan ajaran iman bersifat prinsip. Bilamana sebuah keluarga mengalami kebingungan acuan moral maka kehidupan di dalam keluarga tersebut tidak akan tenang. Keluarga yang mengalami kebingungan seperti itu, sangat sukar untuk bisa menciptakan suasana damai sejahtera dan tenang. Manakah yang harus dipegang dan manakah yang benar, sebab semua diakui kebenarannya. Maka dari pandangan psikologis, Potensi kekaburan jati diri keluarga akan memicu lahirnya stress personal maupun komunal. Komunikasi akan menjadi terhambat, dan suasana kebersamaan dalam keluarga akan menjadi sangat terganggu. Di sini akan tercipta suatu pola baru yang disebut sebagai "budaya bisu" dalam keluarga, dimana komunikasi tidak akan berjalan dengan sehat. Mempertahankan diri dalam ketertutupan tanpa komunikasi akan menyengsarakan diri sendiri. Keluarga yang hidup bersama dengan tanpa komunikasi yang sehat, akan menimbulkan rasa frustrasi dan jengkel di dalam jiwa anggota keluarga ${ }^{22}$.

\section{Pluralisme Sebagai Masalah Teologi Pastoral}

Problem pastoral di sini ialah potensi akomodatif / sinkritisme dan bahaya dogmatism. Para pelayan pastoral dalam mensikapi pluralisme selalu ada kecenderungan untuk memilih satu sikap ektrim dari dua kemungkinan. Sikap ekstrim pertama ialah menyambut dengan semangat pandangan-pandangan pluralis tanpa sikap kritis dan menolak dengan tegas-tegas apa-apa yang dimilikinya selama ini tanpa suatu pertimbangan yang matang. Barangkali ada keluarga yang menganut paham akomodatif akan mencoba untuk menetralisir semua pandangan yang dianut dalam keluarga untuk saling menerima dan mengakui dan bisa menciptakan suatu suasana yang harmonis. Namun kalau usaha tersebut tidak dilakukan dengan sikap kritis, maka usaha itu akan segera menghantar keluarga tersebut kepada sikap sinkritsme. Jadi upaya untuk menyelamatkan keluarga dengan semangat pluralis akan jatuh ke dalam bahaya sinkritisme. Ini juga sangat berbahaya.

Bagi keluarga yang mengambil sikap tersebut, "Segala suatu dianggap seperti "mode" yang diciptakan menurut selera musim, lantas disingkirkan untuk diganti dengan mode yang lain". ${ }^{23}$ Sikap semacam ini sangat terbuka peluang untuk jatuh ke dalam bahaya sinkritisme. Sinkritisme yang saya maksud ialah bukan soal-soal yang hanya sematamata berhubungan dengan hal-hal mistis atau penyembahan berhala, melainkan penggunaan istilah-istilah dari disiplin ilmu sosial misalnya soal dosa disamakan begitu saja dengan istilah "id" dari psikoanalisa Freud. Penyamaan istilah-istilah teologi dengan istilah-istilah non teologi, menurut 
saya, adalah suatu bentuk sikritisme baru, karena setiap disiplin ilmu, ia mempunyai istilah-istilah yang khas dengan makna yang khas pula dan tidak bisa disamakan begitu saja.

Ketercabutan dari akar tradisi pastoral gereja. Dalam pelayanan pastoral, referensi yang dipakai adalah referensi ilmu-ilmu social seperti psikologi, sosiologi atau ilmu kedokteran, dll. meskipun para pelayan pastoral itu tidak memiliki pengetahuan dasar yang memadai untuk bidang yang direfrensi tersebut. Pola-pola tradisi dari pastoral telah ditinggalkan. Pola-pola tradisi yang saya maksud ialah Alkitab, sejarah pelayanan pastoral dari gereja di masa lampau, teologi pastoral dan sejenisnya. Tradisi tersebut sudah ditinggalkan oleh para pelayan pastoral hari ini.

Meninggalkan Alkitab. Hal tersebut dapat kita saksikan di dalam berbagai khotbah dewasa ini. Dalam sebuah khotbah bukan lagi pesan Alkitab yang mau disampaikan tetapi para pelayan pastoral mengembangkan cerita-cerita pengalaman dari berbagai macam suku dan budaya maupun pengalaman dirinya sendiri. Pembiasaan seperti ini sadar atau tidak sadar akan segera membentuk suatu persepsi baru yaitu bahwa cerita-cerita besar dari berbagai suku bangsa tersebut, sama nilainya dengan cerita-cerita besar dalam Alkitab. Jika hal ini yang terjadi, maka gereja telah menjadi agen untuk paham pluralism, yaitu menghapus metanarasi dan menggantikannya dengan cerita-cerita rakyat dari berbagai budaya dan agama. Tanpa disadari bahwa dengan cara tersebut para pelayan pastoral telah menciptakan "Alkitab baru" yang penuh dengan kisah-kisah pengalaman dari masing-masing individu.

Sikap ekstrim lainnya ialah bahaya dogmatisme. Berseberangan dengan kelompok akomodatif ialah kelompok yang mencoba menutup diri dengan nama dogma. Bagi kelompok ini bila berhadapan dengan paham pluralisme, mereka segera "menutup diri, membuat kepompong baja, seraya memperkuat sikap mengagung-agungkan serta memutlakkan apa yang dipunyai dan merelatifkan apa yang tidak dipunyai". Hal tersebut dapat dipahami oleh karena keyakinan agama selalu bersifat dogmatis yang tidak pernah memberi tempat pada keraguan dan pertanyaan.

\section{IMPLIKASI PASTORAL}

Di tengah silang pendapat dan pandangan dari para teolog di sanasini mengenai pluralisme, para petugas pastoral sebaiknya tidak usah terjebak dalam perdebatan yang melelahkan itu. Para pelayan pastoral harus tetap setia pada komitmentnya untuk memelihara jemaat Tuhan (2 Korintus $11: 28$ ) Kadang para pelayan pastoral tergoda untuk melakukan tindakan konfrontasi dan mengeluarkan anggota gereja yang sangat mendukung semangat pluralism. Sikap ini tidak perlu diambil, sebab mereka yang senang dengan paham pluralisme itu bukanlah musuh kita (2 
Tesalonika $3: 15)$. Terkadang pula para pelayan pastoral tergoda untuk bertindak masa bodoh terhadap apa yang sedang terjadi. Sikap inipun tidak perlu diambil, sebab memang tugas pastoral ialah berusaha untuk selalu mengingatkan (1 Timotius $4: 6$ ) jemaat akan segala hal yang membawa mereka kepada kesempurnaan hidup. Jika demikian sikap seperti apakah yang perlu diambil oleh para pelayan pastoral? Pada bagian-bagian sebelumnya saya sudah menyinggung bahwa Alkitab dan tradisi pastoral sudah ditinggalkan dalam pelayanan pastoral, maka di bawah ini saya akan memperjelas apa yang saya maksud dengan pernyataan tersebut.

\section{Kembali Kepada Alkitab}

Kita tentu masih ingat akan semangat Martin Luther dengan "Sola Scriptura"nya yang menggoncangkan dunia. Ketika itu dunia hampir dapat dikatakan sudah dan sedang dikuasai oleh semangat filsafat dan teologi abad pertengahan. Keadaan itu membuat gereja lupa akan firman Tuhan, para pemimpin gereja terjebak ke dalam diskusi yang tak pernah selesai tentang filsafat, teologi dan ilmu pengetahuan. Tentu diskusi-diskusi semacam itu tidak salah tetapi apa yang salah ialah bahwa diskusi itu sudah semakin jauh meninggalkan alkitab. Maka di sanalah Martin Luther hadir dan menyerukan untuk kembali kepada Alkitab.

Apa yang saya mau sampaikan dengan kalimat kembali kepada Alkitab? Yang saya mau katakan ialah bahwa para pelayan pastoral hendaknya membaca ulang Alkitab dengan teliti dan perlahan-lahan. Sebab hanya dengan sikap membaca yang demikian kita akan menemukan bahwa Alkitab sudah menyajikan kepada kita berbagai kemungkinan untuk kepentingan kebersamaan kita. Alkitab sebagai sumber bagi pelayanan pastoral sudah menyediakan kepada kita berbagai cara dengan segala kekayaannya untuk kepentingan pemeliharaan domba-domba milik Tuhan. Kalau kita perhatikan dengan teliti dan tidak tergesa-gesa, kita akan segera menemukan kepelbagaian yang sangat kaya di dalam Alkitab. Membaca dengan teliti membutuhkan kemauan untuk mendengarkan. Kitab suci yang tidak didengar akan menjadi tidak menarik, tidak akan memberi inspirasi.

Mendengarkan artinya bersedia membuka hati, membuka diri, bersedia menerima, berpikir dan merenungkan serta mengelola apa yang didengar. Jadi sebagai pelayan pastoral janganlah kita terjebak ke dalam satu pandangan yang ekstrim, apakah pandangan eksklusif, inklusif ataupun pluralis. Janganlah kita melihat padangan-pandangan itu sebagai yang saling bertentangan dan saling meniadakan. Pandangan-pandangan tersebut hendaknya dilihat sebagai kekayaan kecerdasan manusia dalam merumuskan pengalamannya dengan Tuhan. Di dalam Alkitab kita bisa menemukan pandangan eksklusif, misalnya dalam Perjanjian lama Allah menyuruh umatNya untuk memisahkan diri dari bangsa-bangsa Kanaan, atau dalam perjanjian baru Tuhan berbicara melalui rasul Paulus bahwa orang percaya tidak boleh menjadi serupa dengan dunia ini. Ini adalah sikap 
eksklusif. Tetapi pada kesempatan lain, baik di dalam perjanjian lama maupun Perjanjian baru, Tuhan memerintahkan kepada umatNya untuk masuk ke dalam dunia dan menjadi terang dan saksi kepada dunia. Ini sikap inklusif. Pada kesempatan lain lagi Alkitab menyodorkan kepada kita bahwa pandangan dari dunia (mereka yang tidak beriman Yahudi atau Kristen) bahwa Tuhan pakai mereka untuk mendatangkan kebaikan bagi manusia, misalnya Yitro mertua Musa, ia adalah seorang imam di Median, (Keluaran 18) toh Tuhan pakai dia untuk memberikan suatu pencerahan kepada Musa. Ini pandangan pluralis. Artinya disamping pandangan-pandangan khas kelompok Israel, ada juga pandangan lain yang sangat berguna untuk memperkaya kekayaan kaum Israel. Masih banyak contoh-contoh lain di dalam Alkitab.

Maka bagi saya, sebagai pelayan pastoral marilah kita membaca ulang Alkitab kita dengan teliti dan perlahan-lahan sehingga kita menemukan mutiara-mutiara yang berhamburan di sana-sini. Membaca ulang di sana bukan untuk kembali kepada cara-cara tempo dulu, melainkan melihat pesan pelayanan pastoral dan makna pemeliharaan umat seperti yang disampaikan di dalam Alkitab. Dengan demikian panggilan pastoral untuk memelihara kawanan domba milik Allah tetap terlaksana dengan baik dan mendatangkan damai sejahtera bagi kita semua.

\section{Jangan Mengabaikan Tradisi}

Dari pengamatan saya belakangan ini, saya memperoleh kesan bahwa ada kecenderungan dari para pelayan pastoral untuk mengabaikan dan melupakan tradisi. Fenomena ini tidak saja terjadi di wilayah pelayanan pastoral, tetapi sudah merambah ke mana-mana, banyak contoh yang bisa kita temui di masyarakat. Melupakan tradisi adalah penyakit masyarakat paska modern. Memang tradisi bisa bersifat negatif, apabila tradisi dipakai sebagai ukuran untuk menentukan segala sesuatu, tetapi lebih lanjut dapat dikatakan bahwa orang tidak bisa maju ke depan dengan tetap terikat pada masa lalu (Filipi $3: 13$ ) sebab bagimanapun kita dibentuk oleh tradisi ${ }^{25}$. Ketika berbicara tentang tradisi yang saya mau katakan ialah soal cara-cara atau kebiasaan dalam pelayanan pastoral. Di dalam Alkitab kita menemukan berbagai cara untuk memelihara iman umat, misalnya dalam tradisi para imam, mereka melakukan tugas pemeliharaan dengan ritualritual dan dalam ritual tersebut hal simbol memainkan peranan yang sangat penting.

Pembatinan nilai-nilai religius ditanamkan melalui ritus-ritus. Ritusritus sebagai sistem simbol-simbol sakral yang berfungsi untuk mensintesiskan suatu etos kerja seperti kualitas kehidupan, moral, gaya estetis, suasana batin manusia. Sistem simbol-simbol sakral juga memberikan gambaran tentang pandangan dunia (world view) suatu bangsa seperti, gambaran yang komprehensif mengenai tatanan hidup 
sebagai bangsa. Simbol merupakan sumber informasi ekstrinsik. Simbol ekstrinsik menyediakan cetak biru yang olehnya proses-proses kehidupan spiritual dapat dibangun dan dibentuk. Sistem simbol menetapkan suasana batin. Orang tidak melihat konsep tentang Tuhan, malaikat, dosa, pengampunan. Tetapi dengan sistem simbol-simbol sakral, manusia diangkat, terbentuk hati nuraninya, untuk mengenal Tuhan, dosa dan pengampunan.

Sistem simbol-simbol sakral membentuk iklim hati, menarik si penyembah ke disposisi khusus tertentu serta memberi suatu ciri tetap pada kualitas pengalaman rohani. Suasana hati itu misalnya khikmad, sahdu, kegembiraan yang meluap-luap, kesedihan yang mendalam, penyesalan yangmendalam, keyakinan yang makin teguh ....dst. Sistem Simbol-simbol keagamaan yang sakral membuat orang untuk sanggup menanggung: Situasi-situasi tekanan emosional. Membuka jalan keluar dari situasi tersebut. dan jalan-jalan buntu, dengan ritus-ritus keagamaan dan kepercayaan yang menghantar orang untuk masuk ke dalam dunia supranatural. Sistem Simbol keagamaan sangat berperan kuat dalam mengatasi situasi krisis dalam kehidupan. Ritual-ritual atau upacaraapacara yang diselenggarakan oleh para imam atas perintah Tuhan, merupakan suatu ungkapan simbolis yang hendak menyatakan bahwa dalam bentuk yang kelihatan realitas persekutuan rohani dengan Allah. Gerak-gerik Imam pada ucapara hari penebusan merupakan ungkapan sesungguhnya dari umat kepada Tuhan dan itu diperkenankan oleh Tuhan dalam kemurahanNya.

Dalam tradisi pastoral lainnya, para pelayan pastoral menggunakan pengurapan dengan minyak dan penumpangan tangan atas mereka yang sakit, pengusiran setan dengan doa-doa dan nyanyian-nyanyian, doa-doa penyembuhan bagi yang sakit, dll. Ekspresi palayanan pastoral dalam tradisi ternyata sangat kaya dan kita bisa menggunakan salah satu atau beberapa cara untuk pelayanan pastoral hari ini. Penggunaan cara-cara seperti disebutkan di atas sudah dipraktekkan dalam tradisi Yudaisme sebelum era kekristenan, kemudian di awal kekristenan cara-cara tersebut masih dipakai dalam pelayanan pemulihan. Dewasa ini gereja-gereja protestan liberal sudah tidak percaya lagi akan hal-hal atau kuasa roh jahat dan tidak lagi menggunakan cara-cara pelayanan pemulihan dengan pengusiran. Sementara di gereja-gereja pentakosta, hal ini masih dilakukan. Dalam sejarah tradisi Katolik dan Ortodoks, masih mempraktekkkan cara - cara tersebut namun dengan pengawasan ketat dari gereja ${ }^{27}$. Dengan mengatakan demikian, saya bermaksud agar janganlah para pelayan pastoral saling "bertengkar" atau mempertentangkan cara-cara penanganan suatu kasus dalam pelayanan pastoral. Hal yang penting ialah bahwa semuanya itu dilaksanakan dengan hati nurani yang murni untuk melayani Tuhan dan bukan untuk mencari popularitas pribadi. Sebab seluruh pelayanan pastoral selalu berkisar di 
sekitar keterbukaan di dalam menghadapi kepelbagaian ${ }^{28}$. Sebagimana kita ketahui bahwa teologia yang sangat dinamis adalah teologi pastoral, sebab ia selalu berada dan hidup di tengah perubahan yang terus terjadi. Dari antara sekian banyak teologi kristen yang berkembang dalam gereja, tampaknya teologia pastoral adalah teologi yang sangat dinamis. Dinamis oleh karena teologi pastoral sebagai suatu cabang teologi yang secara sistimatis mengadakan refleksi tentang kehidupan gereja di tengah dunia. Kehidupan gereja dan tugasnya tidak akan pernah selesai sebelum Sang kepala gereja itu datang kembali, maka disini perlunya keterbukaan. Keterbukaan tersebut perlu diiringi dengan kemauan untuk mendengarkan sehingga dapat menangkap perasaan yang terdalam dari berbagai perbedaan. Bahasa manusia selalu berbeda, tetapi perasaan-perasaan manusia selalu sama. Oleh karena itu dalam pelayanan pastoral yang berhubungan dengan manusia dalam konteksnya para pelayan pastoral perlu belajar untuk menangkap pesan-pesan terdalam dari berbagai perasaannya. Maka disana kita tidak hanya berbicara dengan otak atau pengetahuan semata tetapi berbicara dengan hati yang penuh empati dan hati nurani yang murni. Dengan mengambil sikap yang demikian, saya rasa bahwa para pelayan pastoral yang sedang bergumul dengan banyak permasalahan pastoral di lapangan, tidak akan terjebak ke dalam sikap saling menyerang dan mempersalahkan, tetapi justru akan mengembangkan suatu semangat kerja sama bagi keluasan kerajaan Allah.

\section{PENUTUP}

Dewasa ini pelayan pastoral berlangsung di tengah-tengah semangat pluralisme. Semangat ini jauh lebih hebat dari masa-masa pelayanan pastoral yang lalu. Akar-akar pemikiran pluralisme sesungguhnya berasal dari perenungan yang lama dan panjang para ahli filsafat sejak jaman Yunani kuno. Tetapi pluralisme yang tengah populer dewasa ini sebenarnya tidak mengalir dari aliran filsafat melainkan dari analisis sosial yang mengasumsikan bahwa konflik sosial yang tengah marak terjadi dipicu oleh pluralisme agama terutama klaim-klaim kebenaran. Maka pluralisme disodorkan sebagai solusi terhadap berbagai konflik sosial yang mengatas namakan kebenaran agama, maka semangat pluralisme sebagai sebuah paham hendaklah kita tanggapi secara kritis.

Berbagai sikap dan reaksi dan tanggapan terhadap pluralisme, namun secara umum dapat dideskripsikan dalam tiga sikap. Pertama, paradigma eksklusivisme merupakan pandangan yang dominan di sepanjang sejarah agama-agama dan tetap dianut pemeluk agama sampai saat ini. Inti pandangan eksklusivisme ialah bahwa agama yang dianut seseorang adalah satu-satunya jalan yang sah, benar menuju keselamatan dan Sorga. Pandangan ini menyebar di semua agama wahyu di seantero dunia ini. Kedua, paradigma "inclusive". Paradigma ini bertolak dari suatu pemikiran bahwa semua agama dengan segala ajarannya, mampu menyediakan jalan 
keselamatan yang dapat menyelamatkan umatnya sejauh mereka (umat) hidup dalam ketulusan hati terhadap Tuhan. Ketiga, Pandangan ketiga Pluralisme. Pandangan ini mengatakan bahwa setiap agama mempunyai jalan keselamatannya sendiri, dan karena itulah semua klaim kebenaran bahwa hanya agamakulah adalah satu-satunya yang agama sah dan benar, harus ditinggalkan.

Semangat pluralisme telah menghadirkan pula kesadaran pluralisme oikumenis di tengah masyarakat gereja. Dalam perjalannya pluralisme oikumenis telah melahirkan konflik baru bagi pelayanan pastoral. Pluralisme oikumenis menjadi problem sosiologis, psikologis dan teologis, khususnya yang berkenaan dengan pelayanan pastoral.

Dalam menghadapi persoalan yang demikian, para pelayan pastoral diminta untuk membangun kembali semangat cinta kepada Alkitab maupun tradisi pelayanan pastoral, sehingga menemukan kembali pesan-pesan pastoral dan makna pelayanan yang lebih mensejahterakan kehidupan rohani umat.

\section{DAFTAR PUSTAKA}

Adiprasetya, Joas. Mencari Dasar Bersama: Etika Global Dalam kajian Postmodernisme dan Pluralisme Agama. Jakarta: BPK. Gunung Mulia, 2002.

Bactiar, Wardi. Sosiologi Klasik: Dari Comte hingga Parsons. Bandung: Remaja Rosda, 2006.

Bagus, Lorens. Kamus Filsafat. Jakarta: Gramedia Pustaka Utama, 1967. Bertens, K. Ringkasan Sejarah Filsafat. Yogyakarta: Kanisius, 1981.

Claeke, Andrew D. dan Bruce W. Winter, Satu Allah Satu Tuhan: Tinjauan Alkitabiah Tentang Pluralisme Agama. Jakarta: BPK. Gunung Mulia, 2002.

Copleston Fredrick. A History of Philosophy : Volume I Grece \& Rome, Part 1. New York: Image Books, 1962.

Coward, Harold. Pluralisme Tantangan Bagi Agama-Agama. Yogyakarta: Kanisius, 1989.

Driver, Tom F. "Masalah Seputar Pluralisme" dalam \& Paul F. Knitter. Mitos Keunikan Agama Kristen. Jakarta: BPK. Gunung Mulia, 2001.

Durkheim, Emile. Suicide: An Study In Sociology. New York: The Free Press, 1967.

Durness, William. Tema-Tema Dalam Teologi Perjanjian Lama. Malang: Gandum Mas, 1992.

Elwood, Douglas J. Teologi Kristen Asia. Jakaarta: BPK. Gunung Mulia, 1993. 
Hadiwijono, Harun. Sari Sejarah Filsafat Barat Jilid 1. Yogyakarta: Kanisius, 1980.

Hardiyanto, Soegeng. (ed) Agama dalam Dialog. Jakarta: BPK. Gunung Mulia, 1999.

Hendropuspito. Sosiologi Agama. Yogyakarta: Kanisius, 1991.

Hommes, Tjaard \& E. Gerrit Singgih. (ed) Teologi dan Praksis Pastoral:

Antologi Teologi Pastoral. Jakarta: BPK. Gunung Mulia, 1992.

Hunter, Rodney J. (ed) Dictionary of Pastoral Care and Counseling.

Nashville: Abingdon Press, 1990.

Mulyono, Bambang Y. Mengatasi Kenakalan remaja, Pendekatan:

Sosiologis, Psikologis, Teologis. Yogyakarta: Yayasan Andi, 1986.

Prent, K. C. M. Kamus Latin - Indonesia. Yogyakarta: Kanisius, 1969.

Sairin, Weinata. Visi Gereja Memasuki Mileniun Baru. Jakarta: BPK. Gunung Mulia, 2002.

Schacht, Richard. Alienasi: Suatu Pengantar Paling Komprehensif. Yogyakarta: Jalasutra, 2005.

Sia Hok Gwan. "Paul Knitter" dalam Jurnal Teologi Gema Duta Wacana, No. 47 tahun 1994.

Singgih, E. G. "Eeuwout Klootwijk" dalam Jurnal Teologi Gema Duta Wacana, No. 47 tahun 1994.

Snijders, Adelbert Manusia Kebenaran. Yogyakarta: Kanisius, 2006.

Sumartana, Th. "Theologia Religionum" dalam Tim Litbang PGI, Meretas Jalan Teologi Agama-Agama di Indonesia. Jakarta: BPK. Gunung Mulia, 1999.

Veeger, K. J. Realitas Sosial: Refleksi Filsafat Sosial Atas Hubungan Individu-Masyarakat Dalam cakrawala Sejarah Sosiologi. Jakarta: Gramedi Pustaka Utama, 1990.

Vos, Gerhardus. Biblical Theology: Old and New Testaments. Grand Rappids: Eerdmans, 1948.

Wahono, Wismoady S. Pro Eksistensi. Jakarta: BPK. Gunung Mulia, 2001. Snijders, Adelbert Manusia Kebenaran, ( Yogyakarta: Kanisius, 2006) h. 133-134.

\section{EndNote}

1. Th. Sumartana, "Theologia Religionum” dalam Tim Litbang PGI, Meretas Jalan Teologi AgamaAgama di Indonesia, (Jakarta: BPK. Gunung Mulia, 1999) h. 26.

2. Andrew D. Claeke dan Bruce W. Winter, Satu Allah Satu Tuhan: Tinauan Alkitabiah Tentang Pluralisme Agama, (Jakarta: BPK. Gunung Mulia, 2002) h. 15 - 19 
3. Fredrick Copleston, A History of Philosophy : Volume I Grece \& Rome, Part 1, ( New York: Image Books, 1962) hal 108. Lihat juga Harun Hadiwijono, Sari Sejarah Filsafat Barat Jilid 1. ( Yogyakarta: Kanisius, 1980) hal 33

4. Soegeng Hardiyanto, (ed) Agama dalam Dialog ( Jakarta: BPK. Gunung Mulia, 1999) h. 309

5. Harold Coward, Pluralisme Tantangan Bagi Agama-Agama, (Yogyakarta: Kanisius, 1989) h. 53

6. Lorens Bagus, Kamus Filsafat, (Jakarta: Gramedia Pustaka Utama, 1967) h. 853. Lihat juga K. Prent C. M. Kamus Latin - Indonesia (Yogyakarta: Kanisius, 1969)h. 650.

7. E. G. Singgih, "Eeuwout Klootwijk" dalam Jurnal Teologi Gema Duta Wacana, No. 47 tahun 1994, h.123

8. Sia Hok Gwan, "Paul Knitter” dalam Jurnal Teologi Gema Duta Wacana, No. 47 tahun 1994, h. 138

9. Hendropuspito, SosiologiAgama, (Yogyakarta: Kanisius, 1991)h. 151-152

10. S. Wismoady Wahono, Pro Eksistensi (Jakarta:BPK. Gunung Mulia, 2001)h. 5

11. K. Bertens, Ringkasan Sejarah Filsafat, (Yogyakarta: Kanisius, 1981)h. 17

12. Adelbert Snijders, Manusia Kebenaran, (Yogyakarta: Kanisius, 2006)h. 133-134.

13. Joas Adiprasetya, Mencari Dasar Bersasama: Etika Global Dalam kajian Postmodernisme dan Pluralisme Agama, (Jakarta: BPK. Gunung Mulia, 2002) h. 74

14. Hendropuspito, SosiologiAgama, ...h. 167

15. Ibid. h. 166

16. Tjaard Hommes \& E. Gerrit Singgih, (ed) Teologi dan Praksis Pastoral: Antologi Teologi pastoral, (Jakarta: BPK. Gunung Mulia, 1992) h. 33

17. Richard Schacht, Alienasi: Suatu Pengantar Paling Komprehensif, (Yogyakarta: Jalasutra, 2005) h. 19

18. . Douglas J. Elwood, Teologi Kristen Asia, (Jakarta: BPK. Gunung Mulia, 1993) h. 221

19. Tom F. Driver, "Masalah Seputar Pluralisme" dalam \& Paul F. Knitter, Mitos Keunikkan Agama Kristen, 2001)h. 313

20. Emile Durkheim, Suicide: An Study In Sociology, ( New York: The Free Press, 1967) h. 152 - 160. Lihat juga K. J. Veeger, Realitas Sosial: Refleksi Filsafat Sosial Atas Hubungan IndividuMasyarakat Dalam cakrawala Sejarah Sosiologi, (Jakarta: Gramedi Pustaka Utama, 1990) h. 153 154

21. Weinata Sairin, Visi Gereja Memasuki Milenium Baru, ( Jakarta: BPK. Gunung Mulia, 2002) h. 86

22. Y. Bambang Mulyono, Mengatasi Kenakalan remaja, Pendekatan: Sosiologis, Psikologis, Teologis, (Yogyakarta: Yayasan Andi, 1986) h. 45

23. Tjaard G. Hommes \& E. Gerrit Singgih, (ed) Teologi dan.... h. 163

24. Ibid, h. 163

25. Tjaard Hommes \& E. Gerrit Singgih, Teologi dan.... h. 182

26. Gerhardus Vos, Biblical Theology: Old and New Testaments, (Grand Rappids: Eerdmans, 1948) pp 161 -164. Lihat juga William Durness, Tema-Tema Dalam Teologi Perjanjian Lama, (Malang: Gandum Mas, 1992) h. 125

27. Rodney J. Hunter (ed) Dictionary of Pasroral Care and Counseling, ( Nashville: Abingdon Press, 1990)h. $387-388$

28. Tjaard Hommes \& E. Gerrit Singgih, Teologi dan ... h. 188. 